\title{
Cinegeo
}

International Journal of Environment and Geoinformatics (IJEGEO) is an international, multidisciplinary, peer reviewed, open access journal.

\section{Evaluating Hyperspectral Vegetation Indices for Estimating Nitrogen Concentration of Winter Wheat in Different Growth Stages}

\section{Metin AYDOĞDU, Hakan YILDIZ, Ediz ÜNAL, Seda KÜLEN}

\author{
Chief in Editor \\ Prof. Dr. Cem Gazioğlu \\ Co-Editors \\ Prof. Dr. Dursun Zafer Şeker, Prof. Dr. Şinasi Kaya, \\ Prof. Dr. Ayşegül Tanık and Assist. Prof. Dr. Volkan Demir
}

Editorial Committee (December 2020)

\begin{abstract}
Assos. Prof. Dr. Abdullah Aksu (TR), Assit. Prof. Dr. Uğur Algancı (TR), Prof. Dr. Bedri Alpar (TR), Prof. Dr. Levent Bat (TR), Prof. Dr. Paul Bates (UK), İrşad Bayırhan (TR), Prof. Dr. Bülent Bayram (TR), Prof. Dr. Luis M. Botana (ES), Prof. Dr. Nuray Çağlar (TR), Prof. Dr. Sukanta Dash (IN), Dr. Soofia T. Elias (UK), Prof. Dr. A. Evren Erginal (TR), Assoc. Prof. Dr. Cüneyt Erenoğlu (TR), Dr. Dieter Fritsch (DE), Prof. Dr. Çiğdem Göksel (TR), Prof.Dr. Lena Halounova (CZ), Prof. Dr. Manik Kalubarme (IN), Dr. Hakan Kaya (TR), Assist. Prof. Dr. Serkan Kükrer (TR), Assoc. Prof. Dr. Maged Marghany (MY), Prof. Dr. Michael Meadows (ZA), Prof. Dr. Nebiye Musaoğlu (TR), Prof. Dr. Masafumi Nakagawa (JP), Prof. Dr. Hasan Özdemir (TR), Prof. Dr. Chryssy Potsiou (GR), Prof. Dr. Erol Sarı (TR), Prof. Dr. Maria Paradiso (IT), Prof. Dr. Petros Patias (GR), Prof. Dr. Elif Sertel (TR), Prof. Dr. Nüket Sivri (TR), Prof. Dr. Füsun Balık Şanlı (TR), Prof. Dr. Uğur Şanlı (TR), Duygu Ülker (TR), Prof. Dr. Seyfettin Taş (TR), Assoc. Prof. Dr. Ömer Suat Taşkın (US), Assist. Prof. Dr. Tuba Ünsal (US), Dr. İnese Varna (LV), Dr. Petra Visser (NL), Prof. Dr. Selma Ünlü (TR), Prof. Dr. Murat Yakar (TR), Assit. Prof. Dr. Sibel Zeki (TR)
\end{abstract}




\title{
Review Article
}

\section{Evaluating Hyperspectral Vegetation Indices for Estimating Nitrogen Concentration of Winter Wheat in Different Growth Stages}

\author{
Metin Aydoğdu, (D) Hakan Yıldız, (DD IEdiz Ünal, (iD Sieda Külen ID \\ Central Research Institute for Field Crops, Geographic Information System and Remote Sensing Department, Yenimahalle / Ankara-TR
}

Received 10 Jan 2020 Accepted 22 Sept 2020

E-mail: metin.aydogdu@ tarimorman.gov.tr

How to cite: Aydoğdu, et al. (2020 Evaluating Hyperspectral Vegetation Indices for Estimating Nitrogen Concentration of Winter Wheat in Different Growth Stages, International Journal of Environment and Geoinformatics (IJEGEO), 7(3): 325-334. DOI: 10.30897/ijegeo.673038

\begin{abstract}
Plant health and plant density can be monitored through indices values calculated from reflectance charateristics of plants. This study aims to investigate the effects of different rates of nitrogen fertilizer on spectral reflectance characteristics of dryland winter wheat and to determine and select the most reliable vegetation indices for Nitrogen $(\mathrm{N})$ status assesment ( $\mathrm{N}$ contents of leaves) of winter wheat canopy in early, late and whole development stages. The field experiment was carried out in randomized block design with three replications and $0,40,80,120,160 \mathrm{~kg} / \mathrm{ha} \mathrm{N}$ doses applied between 2012-2013 years in İkizce Farm experiment field. In each plot, spectroradiometer readings were taken during growing period from planting to harvest various plant vegetation indices (NDVI, RDVI, SAVI, MTVI, MCARI-1, MCARI-2, TCARI, TVI, SIPI, NPCI, Red Edge (750-700), Red Edge (740-720)) were calculated from measured spectroradiometric values. A total of 90 different indices were calculated to obtain the relationship between nitrogen accumulation and hyperspectral indices (structural, chlorophyll pigment, red edge indices). The simple linear determination coefficients $\left(\mathrm{R}^{2}\right)$ between those indices and leaf nitrogen contents in different development stages of early, late, and whole season were calculated. During the early period of tillering to bolting, (Feekes 4-7) NDI-1, NDI-2, SR-7, Red Edge indices (708-850 nm.) have the highest determination coefficients $\left(\mathrm{R}^{2}\right)$ of 0.643, 0.641, 0.620 with RMSE values of 5.996, 6.039, 6.129 and relative percentage error values (\%RE) of 23.07, 23.23, $23.58 \%$ respectively. During the period of heading to ripening (Feekes 8-10), PhRI, NDV-3, NDVI-4 visible (Green Zone), red, red edge and near infrared (NIR) indices (531-800 nm.) showed the highest determination coefficients of $0.734,0.708,0.699$ with RMS values of 3.089, 3.205, 3.149 and relative percentage error values of $40.37,41.89,41.16 \%$ respectively. Considering all growing period in 2013 of tillering to ripening, ( Feekes 4-10); SR-14, SRPI, TVI visible area (blue + green) and Red Edge indices $(415-750 \mathrm{~nm}$.) have determination coefficients of 0.742, 0.699, 0.646 and RMS values $1.203,0.902,0.697$ and relative percentage error values of 7.15, 5.36, $4.14 \%$, respectively. High determination coefficient $\left(\mathrm{R}^{2}\right)$ between plant nitrogen uptake and reflectance charecteristics were attained as HVI $(\mathrm{r}=0.806 \mathrm{p}<0.0 .1 * *)$, OSAVI $(\mathrm{r}=0.794$, $\left.\mathrm{p}<0.0 .1^{* *}\right)$, NDVI $\left(\mathrm{r}=0.794, \mathrm{p}<0.0 .1^{* *}\right)$ and HNDVI $(\mathrm{r}=0.793, \mathrm{p}<0.0 .1 * *)$.
\end{abstract}

Keywords: Hyperspectral, spectroradiometer, vegetation indices, remote sensing, wheat, leaf area indice (LAI),

\section{Introduction}

One of the most important factors affecting wheat production is nitrogen application and irrigation. Necessary amounts and timely application of nitrogen fertilizer is important not only for good yield but also for the quality of the product. In this respect, it is important to determine the nitrogen content in crop. Today, the determination of nitrogen content is performed by conventional chemical methods on the plant samples. These methods are insufficient for identifying nitrogen content quickly without destroying plants. It is possible to reveal specific plant variables quickly and accurately by remote sensing techniques. It is easy to predict different growth variables by spectral indices that are calculated from spectral reflectance values (Currain P.J. 1989). By integrating geographic information systems and remote sensing technology to estimate the biophysical data is mostly focused on the issues of plant biomass measurement (Aparicio, et al. 2000; Üstüner, et al., 2014), leaf area indice (Turner, et al 1999), evapotranspiration estimation and chlorophyll (Zarco-
Tejada, et al 2003; Nasirzadehdizaji et al., 2019). Spectral indices can be obtained from an individual leaf measurement and from the plant canopy measurements (Carter, et al 2002). Spectral indicators used in the determination of plant growth may be single band or multiband (Gamon, et al 1992). The most powerful indice is NDVI between leaf area and canopy of wheat (Fernandez, et al 1994). The fact that reflectance values in the red band are inversely related with the amount of chlorophyll in the plant, but reflectance values in the near-infrared band are directly associated with leaf area (Tucker, 1979). Spectral indices are widely used for the comparison of different growth models at regional and global scale in agricultural applications (Elvidge and.Chen 1995). Especially, spectral signatures of red and near infrared bands from which most known and frequently used indice, NDVI, can be calculated to estimate plant's nitrogen content (Esetlili et al., 2018). Growing period of plants has a significant impact on the selection of sensitive band and on the relationship between nitrogen concentration and Hyperspectral indice value (Sefa and Küçük, 2020). Indice values calculated 
from the range of red and near-infrared show better performance than visible band in the first stages of development (Feekes 4-7). In the late stage of growth (Feekes 8-10), sensible bands which located on ultraviolet, purple and blue band region is more effective in determining the plant's nitrogen content (Feng Wei,et al. 2008; Fava, et al. 2009; İmamoğlu and Sertel, 2016). Blue band is relatively more sensitive for determining the nitrogen content of wheat and rice. Red bands located in near infrared region are more effective in the analysis of aboveground plant biomass and leaf area indice (LAI) of such structural variables. However, bands in visible region are the most affected by mainly from plant chlorophyll content and nitrogen concentration.

Particularly it is necessary to develop new approaches to determine the plant's nitrogen concentration in the early stage. That's why, new methods using more bands were developed such as multiple regression models, Partial Least Squares Sum (PLS), and artificial neural networks (ANN) (Stroppiana,et al. 2009 ; Hansen, and Schjoerring, 2003;Kahriman et al.,2016).Decrease in the concentration of chlorophyll in the leaves is due to nitrogen deficiency (Penuelas, et al. 1995). Plants give higher reflecance in the red region in nitrogen deficiency. The increase in the reflection of the red region indicates chlorophyll deficiency caused by nitrogen reduction, while the decrease in reflectance of the near infrared region indicates the reduction in leaf area indice and green biomass (Bagheri, 2016). Hyperspectral indices can be used together with multispectral indices for an accurate estimate of vegetation parameters. Structural indices are obtained from reflectance readings in the red zone and near infrared (NIR). Reflectances in NIR region is directly controlled by the inside of the leaf structure (Das et al., 2016). The reaction within interior mezophyll structure of cell wall and inter celullar air spaces gives high reflectance in NIR region. Red-NIR spectral passage region (700-750 $\mathrm{nm}$ ) is called red edge and gives a broad overview of vegetation. This region is affected by the combined impact of strong chlorophyll absorption in the red wavelengths and wavelengths in the near infrared. The slope of this region is a strong indicator of a healthy plant.

The purpose of this study is to investigate relationship between leaf nitrogen content and the spectral reflectance properties of the canopy under non-irrigated conditions to determine plant nitrogen uptake for winter wheat in different phenological stages under the various nitrogen application doses (0-40-80-120-160 kg/ha). It is also aimed to develop reliable regression equations with optimum band combinations for estimating the nitrogen concentration of wheat crop during different phenological stages.

\section{Material and Methods \\ The Climate and Soil Features of Experiment Location}

The experiment was conducted in Haymana Experiment Farm of Field Crop Research Institute, Ankara, Turkey at
$39.6132510 \mathrm{~N}$ latitude and $32.6716390 \mathrm{E}$ longitudes, during the 2012-2013 cropping season (Figure 1). This area is characterised by terrestial climate hot in the summer, cold and rainy in the winter. The main crops are wheat and barley in the region. The soil analysis of the experimental field as follows; soil texture is clay loam, water holding capacity $62.50 \%$, salinity EC (dS m-1) $0.610,0.025 \%$ of, $\mathrm{pH} 7.57$, Lime $37.81 \%$ (high lime). Organic matter content were found low $(1.22 \%)$, the amount of organic carbon was $0.71 \%$.

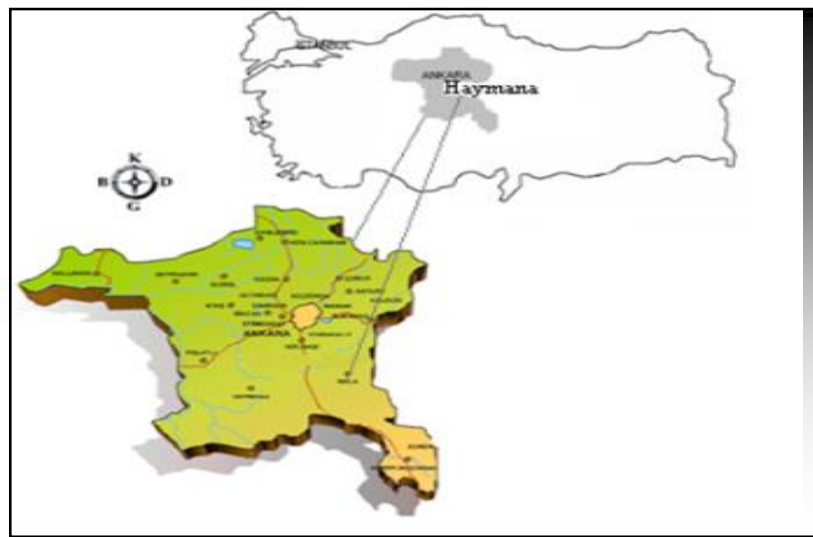

Fig. 1. Haymana--Ankara Experiment Area.

\section{Description of the experiment}

Experimental plots were designed by randomized block design with three replications. The Plots size was 6 by $30 \mathrm{~m}\left(180 \mathrm{~m}^{2}\right)$, row space was $15 \mathrm{~cm}$. A local winter wheat variety "Ikizce" was sown on October 15, 2012 with $200 \mathrm{~kg} / \mathrm{ha}$ seed rate. Nitrogen fertilizer was applied at 5 different doses (0-40-80-120-160 kg N/ha). $55 \mathrm{~kg} / \mathrm{ha}$ Phosphorus (P2O5) and $21 \mathrm{~kg} / \mathrm{ha} \mathrm{N}$ fertilizer was applied as Diamonyum Phosphate (DAP) during planting. The remaining $\mathrm{N}$ fertilizer was applied in early spring as top dressing in the form of Ammonium Nitrate (33\%). The half of the each plot was allocated for collecting biophysical properties (\% canopy cover, LAI, biomass etc.) For different growing periods, remainig part of the plots was harvested to determine grain yield.

\section{Collection of hyperspectral data and data analysis Spectral reflectance measurement}

Canopy reflectance measurements were taken using portable hand-held spectroradiometer instrument, in cloudless conditions from 11 am to $15 \mathrm{pm}$. The hyperspectral device measures visible (VIS) and near infrared (NIR) spectrum in the $3311141 \mathrm{~nm}$ wavelenght domains with the sampling interval $3 \mathrm{~nm}$. Before the spectral reflectance measurements, spectroradiometer was calibrated with white reference plate covered with Ba2SO4. Measurement was taken from a height of 70 $\mathrm{cm}$ and viewing angle of 250. Spectral reflectance values obtained in every parcel with minimum of three readings (parcel beginning, middle and end) and then these measurements were averaged. Biomass was calculated in each plot by cutting above ground vegetation inside a quadrat of $0.25 \mathrm{~m} 2$ area. Biomass samples were dried in oven at $70{ }^{\circ} \mathrm{C}$ during two days and then weighed and grounded. Nitrogen content was determined using 
Dumas Technique (Paul, St., 2000). The plant N uptake was calculated by multiplying $\mathrm{N}$ concentration by dry biomass (g kg-1).

\section{Data analysis and selection of hyperspectral Indices}

There are many vegetation indices (Table 1) improved in recent years to estimate $\mathrm{N}$, chlorophyll or other pigments (Fe.Li et al. 2008, 2010). Different arithmetic formulas have been developed called by vegetation indice to determine spectral response of vegetation on different spectral regions. Generally, these indices can be divided into three groups as structural, chlorophyll and red edge indices.

The spectral readings were obtained during four different developing periods in Haymana. The readings obtained from different development periods were divided into two part stages in order to understand the effects of the growth phase. Because, there is no canopy in the early period and the soil surface is completely covered with canopy in the second period.One of them is early period which includes heading stage (feekes 4-Zadoks 30) (April 25,2013) and the second leaf node formation period (feekes 7, Zadoks-32) (May 07,2013). The other is the late period which includes the new formation of last leaf stage (feekes 8, Zadoks-37) (June 06, 2013) and completed formation of last leaf stage (feekes 10, Zadoks-45) (July 04,2013).

Correlation and regression analyses were carried out using SPSS 22 software.The performance of the models tested by coefficient of determination (R2), comparing Root Mean Squares Error (RMSE) and Relative Percentage Error (RE \%). The larger the R2 and the smaller the RMSE and RE \%, the higher the precision and accuracy of the model.

Table 1. Summary of some different hyperspectral indices used in this study

\begin{tabular}{|c|c|c|}
\hline INDICES & EQUATION & REFERENCE \\
\hline \multicolumn{3}{|c|}{ STRUCTURAL INDICES } \\
\hline $\begin{array}{l}\text { NDVI(Normalized } \\
\text { Difference Vegetation } \\
\text { Indice) }\end{array}$ & $\left(\rho_{n}-\rho_{r}\right) /\left(\rho_{n}+\rho_{r}\right)$ & Rouse et al. (1973) \\
\hline SR (Simple Ratio) & $\rho_{n} / \rho_{r}$ & Birth \& McVey (1968) \\
\hline $\begin{array}{l}\text { RDVI(Renormalized } \\
\text { Difference Vegetation } \\
\text { Indice) }\end{array}$ & $R D V I=\left(R_{800}-R_{670}\right) /\left(R_{800}+R_{670}\right) 0,5$ & Rougean and Breon (1995) \\
\hline $\begin{array}{l}\text { SAVI (Soil Adjusted } \\
\text { Vegetation Indice) }\end{array}$ & $\begin{aligned} S A V I= & \left(R_{800}-R_{670}\right)(1+L) /\left(R_{800}+R_{670}+L\right) \\
& \text { Where } L=0,5\end{aligned}$ & Huete (1988) \\
\hline MTVI & $M T V I=1.2^{*}\left[1.2^{*}\left(R_{800-} R_{550}\right)-2.5\left(R_{670-} R_{550}\right)\right]$ & Haboudane et al. (2004) \\
\hline \multicolumn{3}{|c|}{ KLOROFIL / PIGMENT RELATED INDICES } \\
\hline $\begin{array}{l}\text { MCARI } \\
\text { (ModifiedCARI) }\end{array}$ & $\mathrm{MCARI}=\left[\left(\mathrm{R}_{700}-\mathrm{R}_{670}\right)-0,2\left(\mathrm{R}_{700}-\mathrm{R}_{550}\right)\right]\left(\mathrm{R}_{700} / \mathrm{R}_{670}\right)$ & Daughtry et al. (2000) \\
\hline MCARI 1 & MCARI1=1,2[2,5 $\left.\left(R_{800}-R_{670}\right)-1,3\left(R_{800}-R_{550}\right)\right]$ & Haboudane et al. (2004) \\
\hline MCARI2 & $\begin{array}{c}\text { MCARI2 }=1,5\left[2,5\left(R_{800}-R_{670}\right)-1,3\left(R_{800}-R_{550}\right)\right] / \\
{\left[\left(2^{*} R_{800}+1\right)^{2}-\left(6 R_{800}-5\left(R_{670}\right)^{0,5}\right)-0,5\right]}\end{array}$ & Haboudane et al. (2004) \\
\hline
\end{tabular}

\begin{tabular}{|c|c|c|}
\hline TCARI & TCARI $=3\left[\left(R_{700}-R_{670}\right)-0,2\left(R_{700}-R_{550}\right)\left(R_{700} / R_{670}\right)\right]$ & Haboudane et al. (2002) \\
\hline $\begin{array}{l}\text { TVI (Triangular } \\
\text { vegetation Indice) }\end{array}$ & $T V I=0,5\left[120\left(R_{750}-R_{550}\right)-200\left(R_{670}-R_{550}\right)\right]$ & Broge and Leblanc (2000) \\
\hline $\begin{array}{l}\text { SIPI (Structural } \\
\text { insensitive } \\
\text { Pigment indice) }\end{array}$ & $\mathrm{SIPI}=\left(\left(\mathrm{R}_{800}-\mathrm{R}_{445}\right) /\left(\mathrm{R}_{800}+\mathrm{R}_{680}\right)\right.$ & Penuelas et al. (1995) \\
\hline $\begin{array}{l}\text { NPCI ((Normalized } \\
\text { Pigment Chlorofil } \\
\text { Indice) }\end{array}$ & $\mathrm{NPCl}=\left(\mathrm{R}_{680}-\mathrm{R}_{430}\right) /\left(\mathrm{R}_{680}+\mathrm{R}_{430}\right)$ & Penuelas et al. (1995) \\
\hline
\end{tabular}

\section{RED EDGE INDICES}

$\begin{array}{ll}\text { RedEdge } 750 \sim 700 & \mathrm{R}_{750}-\mathrm{R}_{700} \\ \text { RedEdge740 720 } & \mathrm{R}_{740} / \mathrm{R}_{720}\end{array}$

\section{Conclusions}

Spectral changes of canopy in wheat under different leaf nitrogen doses obtained from different development periods. There are two main factors affecting the state of nitrogen in wheat leaves. The first of these, the nitrogen concentration of the leaf and the other one is leaf nitrogen accumulation. Plant nitrogen uptake in the experimental plots for different development periods changed between $29.67 \mathrm{~g} \mathrm{~kg}-1$ and $37.051 \mathrm{~g} \mathrm{~kg}-1$ (average $16.796 \mathrm{~g} \mathrm{~kg}-1$ ). Plant nitrogen concentration in the early development period (4-7 Feekes) has higher
Gitelson \& Merzylak (1996)

Vogelmann et al. (1993) variation $(62,45 \%)$ than late development period (8-10 Feekes) variation (20.90\%) (Table 2). Plant growth period has a significant impact in selection of sensitive wavelengths for estimating the nitrogen concentration and the performance of different vegetation indice.

Table 2 explains that depending on increasing dose of nitrogen application, wheat plants enters into a rapid development process especially to increase the level of nitrogen absorption in the period up from to the beginning of bolting to the flowering. During the period of the plant development, significant changes are observed in both canopy structure and biochemical 
features. The plant's spectral reflectance properties also vary according to the stage of growth.

Table 3 explains changes in plant nitrogen uptake at different growth stages of wheat, depending on increasing nitrogen doses. Spectral reflectance properties of the canopy especially in the early period from tillering to bolting, it has also been seen low reflectance in visible region (VR) and high reflectance bands in near infrared (NIR) region. In the late stage of growing from heading to ripening phase, high reflectance in visible region and low reflectance in near infrared (NIR) region could be distinguishable.

Table 2. Concentration values of leaf nitrogen $(\mathrm{g} / \mathrm{kg}-1)$ in early and late developing periods.

\begin{tabular}{|c|c|c|c|c|c|c|c|c|}
\hline Period & Stages & Growing Stage & $\begin{array}{l}\text { Sample } \\
\text { (n) }\end{array}$ & $\begin{array}{l}\operatorname{Min} \\
\left(\mathrm{g} \mathrm{kg}^{-1}\right)\end{array}$ & $\begin{array}{l}\operatorname{Max} \\
\left(\mathrm{g} \mathrm{kg}^{-1}\right)\end{array}$ & $\begin{array}{l}\text { Average } \\
\left(\mathrm{g} \mathrm{kg}^{-1}\right)\end{array}$ & $\begin{array}{l}\text { Standart } \\
\text { Daviation } \\
\text { (SD) }\end{array}$ & $\begin{array}{l}\text { CV } \\
(\%)\end{array}$ \\
\hline \multirow{3}{*}{ 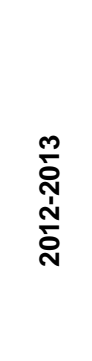 } & $\begin{array}{l}\text { EARLY } \\
\text { GROWING } \\
\text { PERIOD } \\
\text { (4-7 Feekes) }\end{array}$ & $\begin{array}{l}\text { Tillering-bolting } \\
\text { (24 April- 2013 } \\
07 \text { May 2013) }\end{array}$ & 30 & 12.544 & 37.051 & 25.943 & 7.90 & 62.45 \\
\hline & $\begin{array}{l}\text { LATE } \\
\text { GROWING } \\
\text { PERID } \\
\text { (8-10 (Feekes) }\end{array}$ & $\begin{array}{l}\text { Heading-Flowering- } \\
\text { Ripening } \\
\text { (04 June 2013-04 July } \\
\text { 2013) }\end{array}$ & 30 & 2.967 & 24.141 & 10.185 & 4.57 & 20.90 \\
\hline & 2013 & All 2013 & 60 & 2.967 & 37.051 & 16.796 & 11.22 & 126.05 \\
\hline
\end{tabular}

Table 3. Variance Analysis for Nitrogen uptake (g kg-1) levels of plant leaf at diferent nitrogen doses $(\mathrm{P}<0,05)$ in

\begin{tabular}{|c|c|c|c|c|c|}
\hline Variety & $\begin{array}{c}\text { Nitrogen } \\
\text { Doses } \\
\text { (kg/ha) }\end{array}$ & $\begin{array}{l}\text { Tillering } \\
(25.04 .2013)\end{array}$ & $\begin{array}{c}\text { Bolting } \\
(07.05 .2013)\end{array}$ & $\begin{array}{c}\text { Flowering } \\
(04.06 .2013)\end{array}$ & $\begin{array}{c}\text { Doug } \\
(04.07 .2013)\end{array}$ \\
\hline \multirow{5}{*}{ 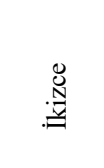 } & 0 & $178.5 \mathrm{~A}$ & $158.1 \mathrm{~A}$ & $53,5 \mathrm{E}$ & $39.9 \mathrm{~A}$ \\
\hline & 40 & $207.6 \mathrm{~A}$ & $157.6 \mathrm{~A}$ & $93.9 \mathrm{C}$ & $43.8 \mathrm{~A}$ \\
\hline & 80 & $347.6 \mathrm{~A}$ & $272.5 \mathrm{~A}$ & 93.1D & $51.4 \mathrm{~A}$ \\
\hline & 120 & $345.7 \mathrm{~A}$ & $289.8 \mathrm{~A}$ & $148.5 \mathrm{~A}$ & $54.8 \mathrm{~A}$ \\
\hline & 160 & $339.0 \mathrm{~A}$ & $297.8 \mathrm{~A}$ & $123.4 \mathrm{~B}$ & $62.7 \mathrm{~A}$ \\
\hline
\end{tabular}

phenological periods

Note: The values in the column are sorted by a minimum degree of importance $(P<0.05)$

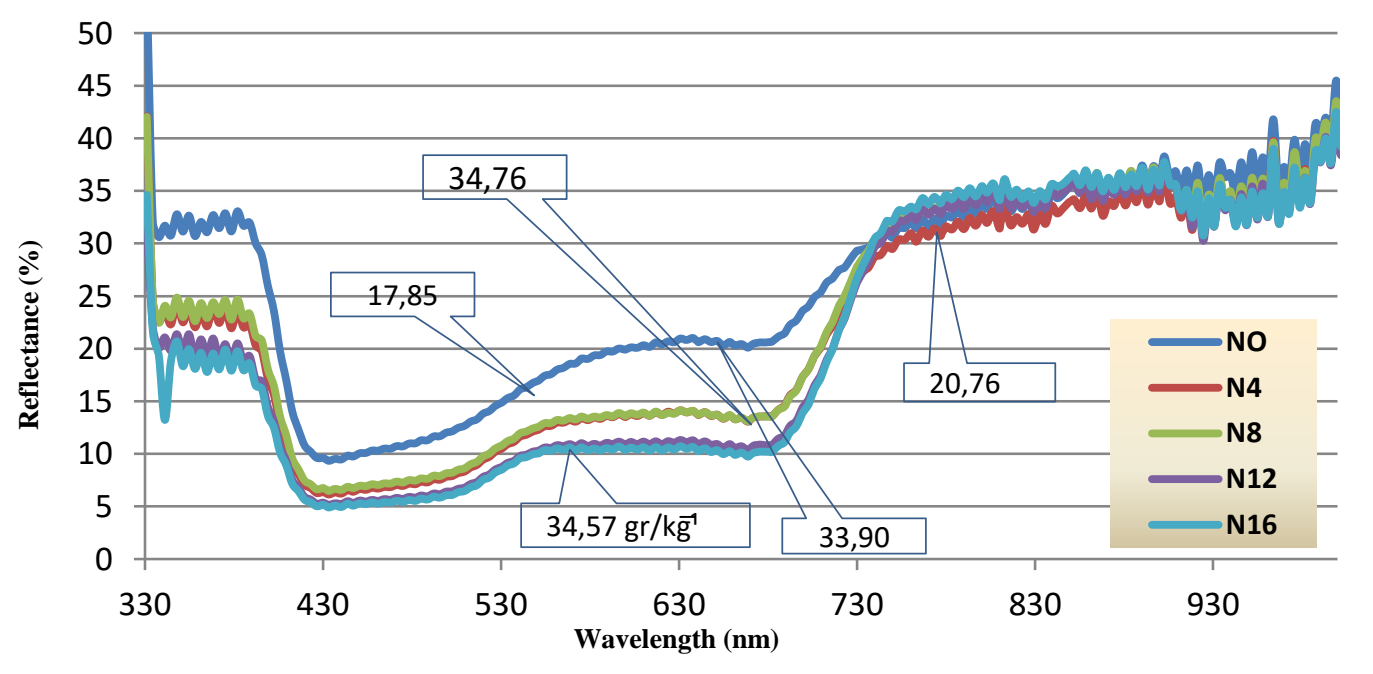

Figure. 2. Spectral reflectance and Leaf nitrogen concentration (LNC) values obtained at the different nitrogen doses during the begining of tillering and end of bolting period in Haymana.

Spectral reflectance values measured at the different nitrogen doses applied during the begining of tillering period and end of bolting period in Haymana (20122013), shown in Figure 2. The highest nitrogen uptake value was observed at nitrogen application of $80 \mathrm{~kg} / \mathrm{ha}$ dose from end of tillering to beginning of bolting (Table 3 ). In Figure 2, hyperspectral reflectance values have shown a declining trend between the values of 330 and
$430 \mathrm{~nm}$ to rising from 430 to $680 \mathrm{~nm}$, finally it showed a sharp rise from 680 to $1141 \mathrm{~nm}$. Considering the different development stages, it has shown similarities between the spectral reflectance values with the values of nitrogen content of leaf (Figure. 2).

Plants grow rapidly as nitrogen accumulation process continues during tillering to bolting period. Especially, it 
reaches relatively high levels in bolting and anthesis. $\mathrm{N}$ remobilization from leaves to wheat grain accelerates from flowering stage to grain filling stage and it reaches maximum level with maturation of the leaves. So, canopy structure and biochemical variables reveal significant differences in to growth phase. Spectral reflectance in the canopy level decrease in the period from tillering to flowering in visible wavebands region and increase in near infrared. In the period from flowering to maturity, spectral reflectance increases in visible region and decreases in near infrared (Figure 3).

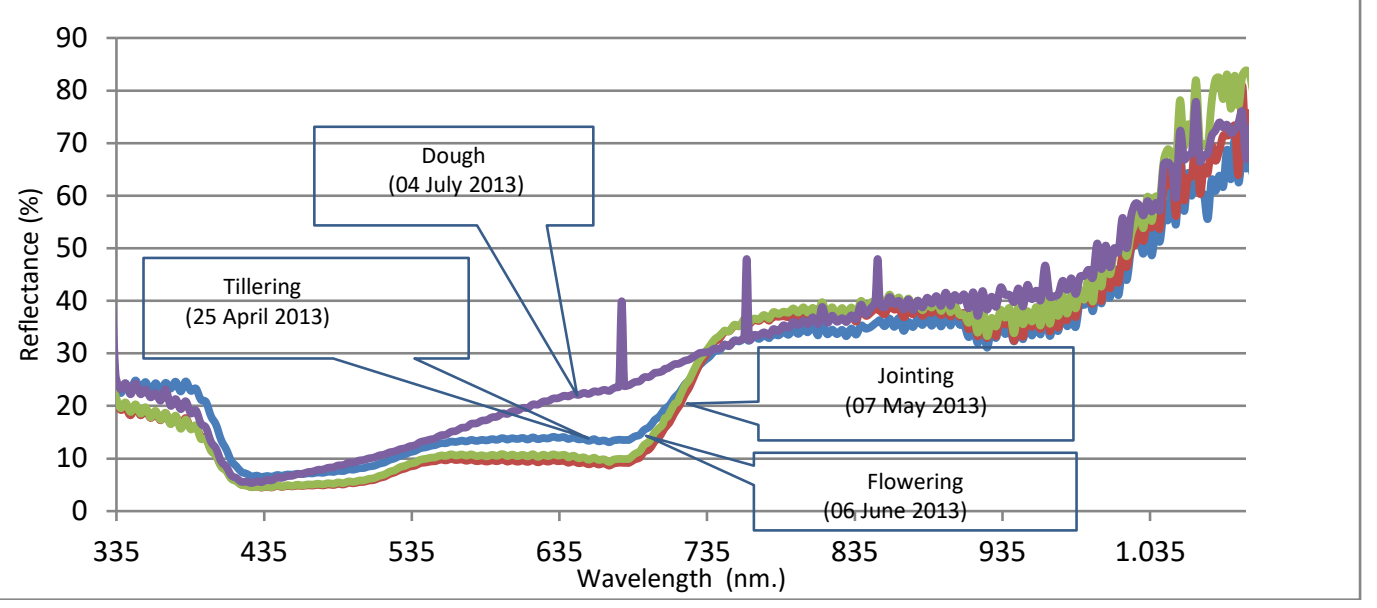

Figure. 3. The relationship between reflectance value (\%) and wavelength $(\mathrm{nm})$ in different growing stages.

Relationship between spectral reflectance values with plant nitrogen content and establishment of regression model

Two classes of indices were calculated using band combinations from spectral band range of 331-1141 nm; Normalized Difference Indice (NDI) and Simple Ratio Indice (SR). The data obtained from three replications of experiment were used to develop regression models. Ninety vegetation indices in a different band combinations were calculated (Structural-56, Chlorophyl-31, Red Edge-3).

Partial Regression Model (PLS) was used to reveal prominent wavelength. For each stage of development (early-late-all year), regression and correlation analysis were conducted between the measured leaf nitrogen concentration and calculated vegetation indices. The accuracy and performance of model was tested for each indice using correlation made with leaf nitrogen (R2), Error Sum of Squares (RMSE) values and Relative Error Percent (RE \%). The Total Square Error (RMSE) (1) and Relative Percentage Error (RE \%) (2) is calculated by the following equation (Fe $\mathrm{Li}$ et al.2008).

$$
\begin{gathered}
R M S E=\sqrt{\frac{1}{n}} \sum_{i=1}^{n}\left(\bar{y}_{i}-\widehat{y} l\right)^{2} \\
R E(\%)=\frac{R M S E}{\bar{y}} 100
\end{gathered}
$$

where $\bar{y}_{i}$, $\widehat{y} \mathbf{l}$ and were $\bar{y}$ measured, predicted values and mean of the measured values of crop variables, respectively. $\mathrm{n}$ was the number of samples.

\section{The Performance evaluating of hyperspectral vegetation indices}

To determine the nitrogen concentration ( $\mathrm{gr} \mathrm{kg}_{-}{ }^{1}$ ), correlation values were evaluated between vegetation indices and leaf nitrogen content based on the different growing periods. Correlation results are given in Table 4 where high performing indices are listed from high to low, but root mean square error of the total value (RMSE) and relative error (\%) are listed from small to large.

When consider the correlation with the indice value from large to small in early stage (25 April, 2013-07 May, 2013), It stands out as the top ten indices; Normalized Difference Indice (NDI-2), Normalized Difference Indice (NDI-1), Simple Ratio-7 Indice (SR-7), Normalized Difference Vegetation Indice (NDVI6),Optimum Vegetation Indice (OVI), Leaf and Canopy Chlorophyll Indice (LCCI), Simple Ratio Pigment Indice (SRPI), Normalized Difference Vegetation Indice (NDVI-2), Modified Chlorophyl Absorbtion Reflectance Indice (MCARI-2), Red Edge(740-720). But then in late stage (06 June, 2013-04 July 2013), top ten indice is Phsiological Reflectence Indice (PhRI), Structural Insensitive Pigment Indice (SIPI), Normalized Difference Vegetation Indice (NDVI-4), NDVI-3, HNDVI, NDVI (Modis), Soil Adjusted Vegetation Indice (SAVI), NDVI, NDVI2 and Optimized Soil Adjusted Vegetation Indice (OSAVI). Finally, in all growing period (2012-2013) (25 April, 2013-04 July 2013), top ten indice can be given as Simple Ratio Indice (SR-14), Simple Ratio Pigment Indice (SRPI), MCARI2, HVI Tringular Vegetation Indice (TVI), LCCI, SR-4, Red Edge (740-720), MSR, NDVI-2. 
Table 4. Calculated statistical values (R2, RMSE, RE \%) between vegetation indices and leaf nitrogen content (gr kg- ${ }^{1}$ ) in different growing stages.

\begin{tabular}{|c|c|c|c|c|c|c|c|c|c|c|c|}
\hline \multicolumn{4}{|c|}{ EARLY STAGE (Feekes 4-7) } & \multicolumn{4}{|c|}{ LATE STAGE (Feekes 8-10) } & \multicolumn{4}{|c|}{ ALL STAGE (2012-2013) } \\
\hline INDICE & $\mathbf{R}^{2}$ & RMSE & $\begin{array}{l}\text { RE } \\
(\%)\end{array}$ & INDICE & $\mathbf{R}^{2}$ & RMSE & $\begin{array}{l}\text { RE } \\
(\%)\end{array}$ & INDICE & $\mathbf{R}^{2}$ & RMSE & RE $(\%)$ \\
\hline $\mathrm{NDI}-2$ & 0.67 & 5.79 & 22.35 & $\mathrm{PhRI}$ & 0.73 & 3.06 & 39.99 & SR-14 & 0.70 & 5.48 & 32.66 \\
\hline NDI-1 & 0.67 & 5.79 & 22.35 & SIPI & 0.72 & 3.49 & 45.66 & SRPI & 0.70 & 5.66 & 33.68 \\
\hline SR-7 & 0.63 & 6.05 & 23.33 & NDVI4 & 0.72 & 3,11 & 40.67 & MCARI2 & 0.63 & 5.92 & 35.25 \\
\hline NDVI6 & 0.53 & 6.61 & 25.49 & NDVI3 & 0.71 & 3.16 & 41.31 & HVI & 0.63 & 5.46 & 32.51 \\
\hline OVI & 0.52 & 6.63 & 25.54 & HNDVI & 0.71 & 3.17 & 41.41 & TVI & 0.63 & 5.68 & 33.81 \\
\hline $\mathrm{LCCl}$ & 0.52 & 6.67 & 25.69 & NDVI(Modis) & 0.71 & 3.17 & 41.49 & $\mathrm{LCCl}$ & 0,62 & 5.59 & 33.26 \\
\hline SRPI & 0.52 & 6.66 & 25.66 & SAVI & 0.71 & 3.18 & 41.55 & SR-4 & 0,62 & 5.38 & 32.05 \\
\hline NDVI2 & 0.52 & 6.67 & 25.72 & NDVI & 0.71 & 3.18 & 41.63 & $\begin{array}{l}\text { Red Edge } \\
(740-720)\end{array}$ & 0,62 & 5.38 & 32.05 \\
\hline MCARI2 & 0.52 & 6.70 & 25.82 & NDVI2 & 0.71 & 3.18 & 41.64 & MSR & 0.61 & 5.84 & 34.77 \\
\hline $\begin{array}{l}\text { Red Edge } \\
(740-720)\end{array}$ & 0.51 & 6.70 & 25.82 & OSAVI & 0.71 & 3.18 & 41.64 & NDVI2 & 0.61 & 5.64 & 33.60 \\
\hline
\end{tabular}

\section{Developing of model}

Regression equations were obtained to reveal relationship between nitrogen contents of plants and indices values calculated from reflectances. Actual $\mathrm{N}$ readings obtained from the plant samples and predicted $\mathrm{N}$ values from different vegetation indices is tetsted with performance comparison by the PLS Model. It is possible to confirm the accuracy of the model in different phenological development stages through R2, RMSE and RE \% values. Regression models were developed based on indices calculated by reflectance measurements of plants and nitrogen contents of the plant samples, according to different phenological periods.In different phenological development stages, the plant samples obtained from $\mathrm{N}$ readings and different vegetation indices help to calculate the estimated total value of the Root Mean Square Error (RMSE) which is then used in comparison of the regression models. The exponential regression model was prefered to explain correlation differenties between indices better than the linear ones.In early period (April 25 -07 May 2013) NDI gives best correlation to predict the nitrogen. NDI-1 $(680-780 \mathrm{~nm}$.), NDI-2 (680-850 nm.) (Figure 4). For the late period (June 6-July 4), NDI-3 (550-780 nm.), PHRI (531-550 nm) (Figure 5), for whole growing period 25 April-July 4) SR-14 (415$695 \mathrm{~nm}$.) and SRPI of $(430-680 \mathrm{~nm}$.) indices seem to be noticeable (Figure 6).

\section{Validation of the model}

Key indices providing the best correlation and regression models were obtained according to results of the analysis between hyperspectral data measured from the wheat canopy and leaf nitrogen content (Table 5) (Fig 7,8,9). All models are tested with the actual data obtained from the test area (Cross-Validation). Thanks to $\mathrm{R}^{2}$, RMSE and RE \% values, that it is possible to confirm the accuracy of the model. All these statistics were performed by using SPSS 22 software program. The reliability of regression models to estimate the leaf nitrogen concentration, was evaluated by comparing the differences in the coefficient of determination $\left(\mathrm{R}^{2}\right)$, root mean squared error (RMSE), and relative error (RE \%) of prediction (Table 5).
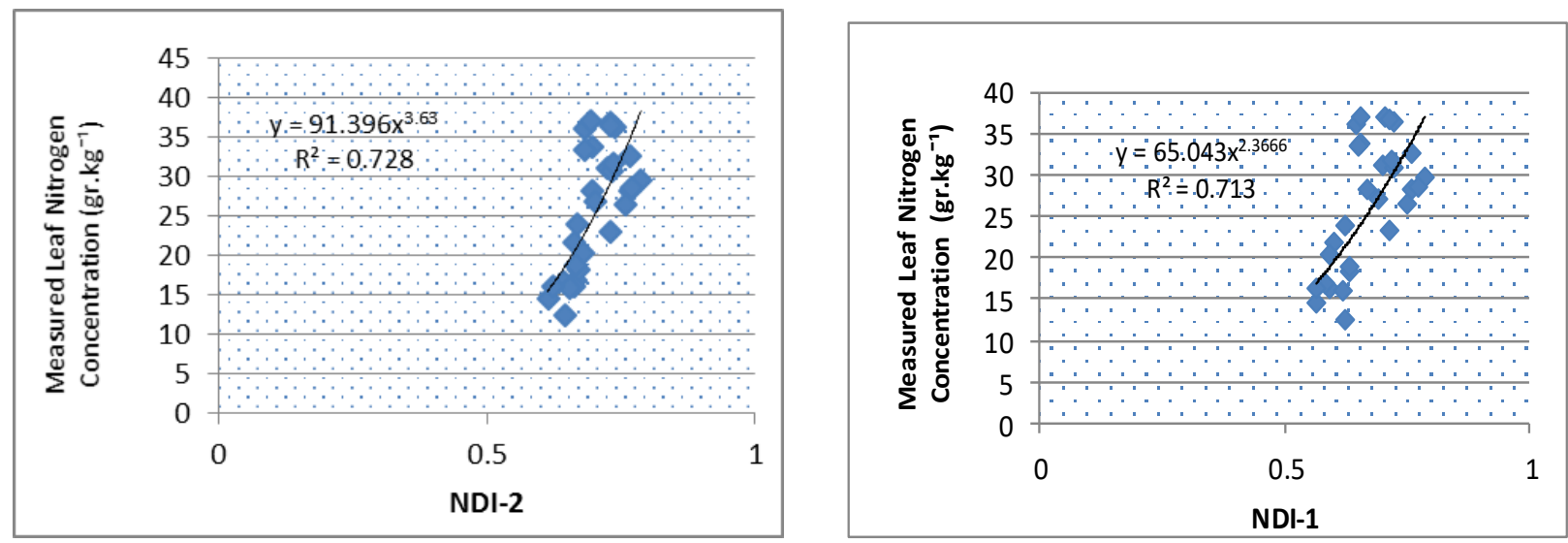

Figure. 4. Exponential relationships between vegetation indices and plant nitrogen content (Early Stage, Feekes 4-7) 

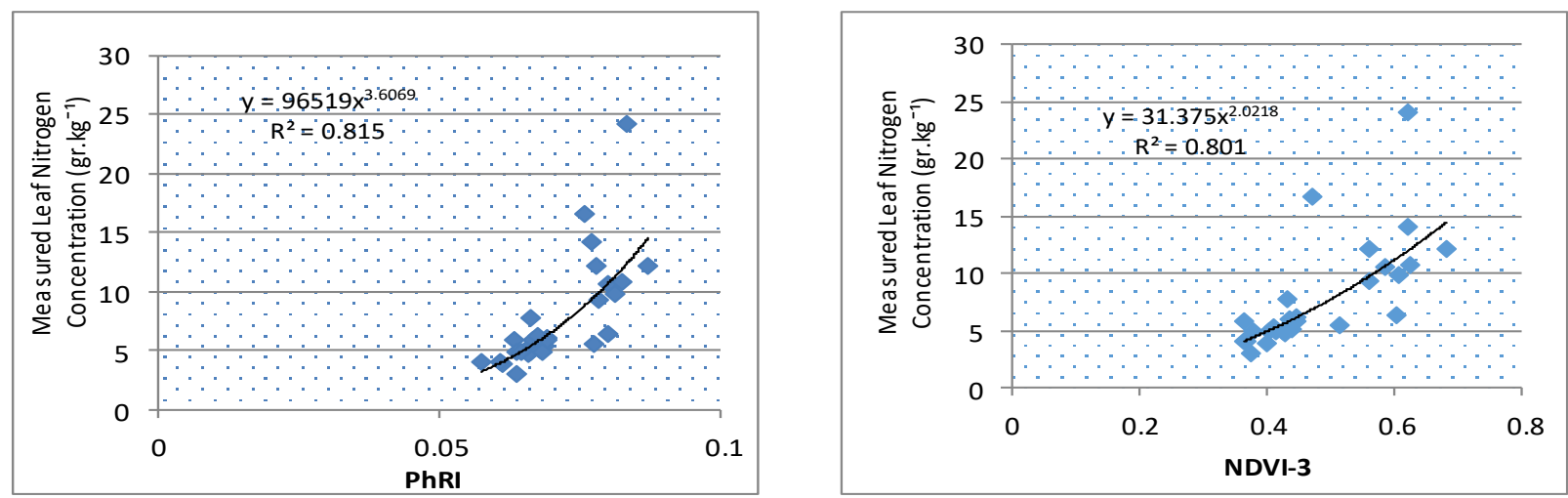

Figure. 5.Exponential relationships between vegetation indices and plant nitrogen content (Late Period, Feekes 8-10)
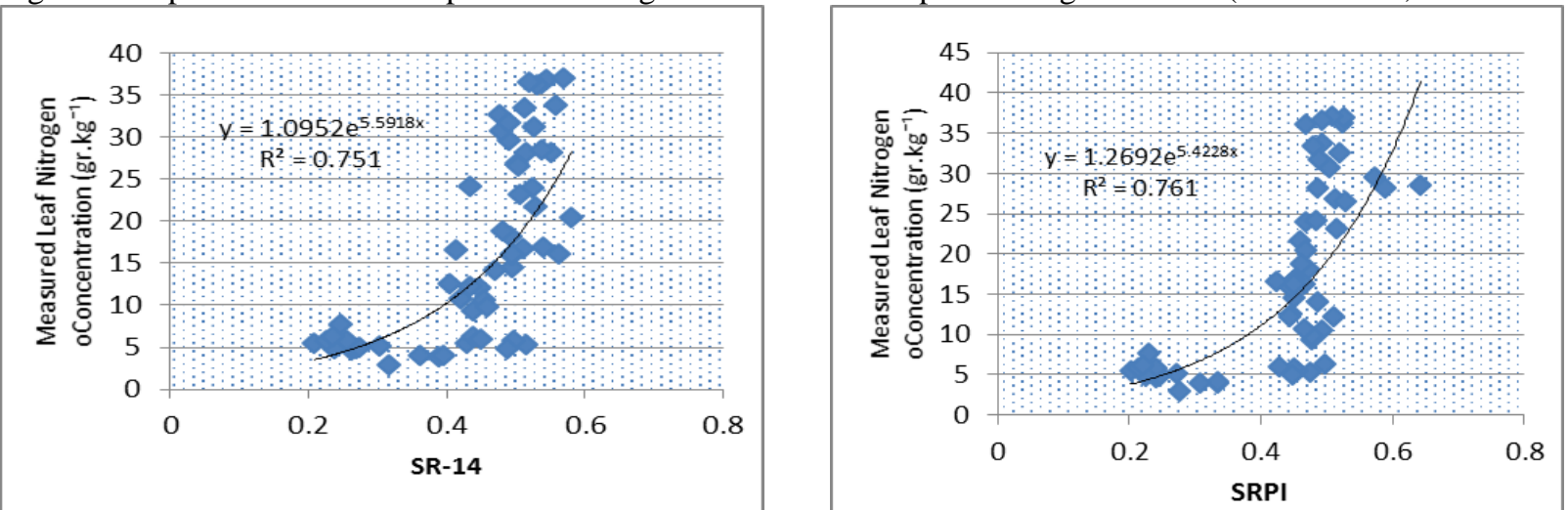

Figure. 6. Exponential relationship between vegetation indices(SR-14; SRPI) and plant nitrogen content (whole Developing Period, Feekes 4-10).

The higher the $\mathrm{R}^{2}$ and the smaller the RMSE and RE, the grater the precision and accuracy of the model to predict leaf nitrogen content.In early stages (Feekes 47 ), best indices to predict plant $\mathrm{N}$ uptake are NDI-1 (680-780 nm.) and NDI-2 (680-850 nm). On the other hand, NDVI-3 (550-780 nm.) and PHRI (531-550 nm.) indices show better performance at the late stages (Feekes 8-10). When considering whole growing period, SR-14 (415-695 nm.) and the SRPI of (430-680 $\mathrm{nm}$.) are noticeable indices.

\section{Discussion}

Due to the increasing dose of given nitrogen, wheat has entered a rapid development process to increase nitrogen absorption levels, especially during the end of tillering and untill the beginning of bolting phase.During this period, significant changes are observed in the structure and biochemical properties of the canopy.Therefore, the spectral reflection properties of the plant also differed based on the growing stages.Phenological development periods are effective in the selection of sensitive hyperspectral bands used to determine the plant nitrogen concentration. The Red and NIR regions are the most sentsitive ranges of electromagnetic spectrum (EMR) to exhibit phenologic and volumetric changes in structural variables such as aboveground biomass and LAI. It' $s$ therefore different indices were used to evaluate the responses of different regions of EMR to changes in monitoring of biomass and LAI alterations during phenologic development.It's found that the nitrogen and chlorophyll concentration of the plant are directly related to the visible region of the spectrum. (Stroppiana et al. 2009). Increments in biomass and LAI in early development stage prevent the exhibition of chlorophyll and nitrogen effect. (Haboudane et al. 2002).

On the other hand, Iin the late period, biomass and LAI have less effect on chlorophyll and nitrogen. When the spectral reflection properties of canopy were examined, low reflection values were observed in visible zone while high reflection values were observed in the near infrared regions of EMR, especially in the period from tillering to bolting.Measured Plant Nitrogen Consantration and estimated indices values of dataset collected from experiment at Haymana location during 2012-2013 were regressed to find out correlations between them.As a result, developed regression models showed the degree of relationships between the various indices values and the amount of nitrogen in the plant at different phenologic periods.The estimated results obtained from the regression equations were calibrated and validated the actual values measured from the experiment (CrossValidation).The best predictors of the regression models testing the relationship between nitrogen concentration and spectral indices were NDI-1, NDI-2, NDVI-3 and NDVI-4 of during early and late development periods. These indices were least affected by different growth periods, years and wheat varieties (Table 5). Performance of the indices also differs with growth stages. The best indices which explain 73 $\%$ of the variation in PNC at late growth stages were PhRI, NDVI-3, NDVI-4 (Feekes 8-10) when the canopy is fully closed, but at earlier stages (Feekes 4-7) NDI-1, NDI-2 indices could explain $64 \%$ variation when the field is partially covered by the canopy. On the other hand, the best indices (SR-14, SRPI) explain $74 \%$ of the variation in PNC at whole growing stages (Feekes 4-10). 
Table 5. According to different development periods prominent indices and regression equations.

\begin{tabular}{|c|c|c|c|c|c|c|c|}
\hline $\begin{array}{l}\text { Growing } \\
\text { Period }\end{array}$ & INDICE & $\begin{array}{l}\text { Wavelength } \\
\text { (nm.) }\end{array}$ & $\mathbf{R}^{2}$ & RMSE & RE (\%) & Regression Equation & Slope \\
\hline \multirow{5}{*}{$\begin{array}{l}\text { Early } \\
\text { Stage }\end{array}$} & $\mathrm{NDI}-1$ & $680-780$ & 0.64 & 5.99 & 23.07 & $y=0.8542 x+4.2905$ & 0.85 \\
\hline & NDI-2 & $680-850$ & 0.64 & 6.04 & 23.23 & $y=0.826 x+4.9822$ & 0.83 \\
\hline & SR-7 & $550-708$ & 0.62 & 6.13 & 23.58 & $y=0.8684 x+3.9893$ & 0.87 \\
\hline & NDVI6 & $708-760$ & 0.56 & 6.45 & 24.82 & $y=0.9286 x+2.5995$ & 0.93 \\
\hline & OVI & $730-760$ & 0.50 & 6.80 & 26.15 & $y=0.7924 x+6.034$ & 0.79 \\
\hline \multirow{5}{*}{$\begin{array}{l}\text { Late } \\
\text { Stage }\end{array}$} & $\mathrm{PhRI}$ & $531-550$ & 0.73 & 3.09 & 40.37 & $y=1.9274 x+11.977$ & 1.93 \\
\hline & NDVI3 & $550-780$ & 0.71 & 3.210 & 41.89 & $y=1.0678 x-0.1099$ & 1.07 \\
\hline & NDVI4 & $600-800$ & 0.70 & 3.15 & 41.16 & $y=1.7924 x+12.94$ & 1.79 \\
\hline & SIPI & $445-800$ & 0.69 & 3.15 & 41.23 & $y=1.7805 x+13.033$ & 1.78 \\
\hline & HNDVI & $668-827$ & 0.60 & 3.23 & 42.25 & $y=1.6777 x+13.873$ & 1.68 \\
\hline \multirow{5}{*}{$\begin{array}{l}\text { All } \\
\text { Stage } \\
(2012- \\
2013)\end{array}$} & SR-14 & $415-695$ & 0,74 & 1.20 & 7.15 & $y=1.2587 x-1.8138$ & 1.26 \\
\hline & SRPI & $430-680$ & 0,70 & 0.90 & 5.36 & $y=1.0947 x+0.5071$ & 1.09 \\
\hline & TVI & $550-750$ & 0,65 & 0.70 & 4.14 & $y=1.2654 x-1.5637$ & 1.27 \\
\hline & HVI & $700-750$ & 0,63 & 0.51 & 3.02 & $y=0.9349 x+2.8362$ & 0.93 \\
\hline & MCARI2 & $550-800$ & 0.61 & 0.54 & 3.21 & $y=1.06 x+1.2638$ & 1.06 \\
\hline
\end{tabular}

NDI-1

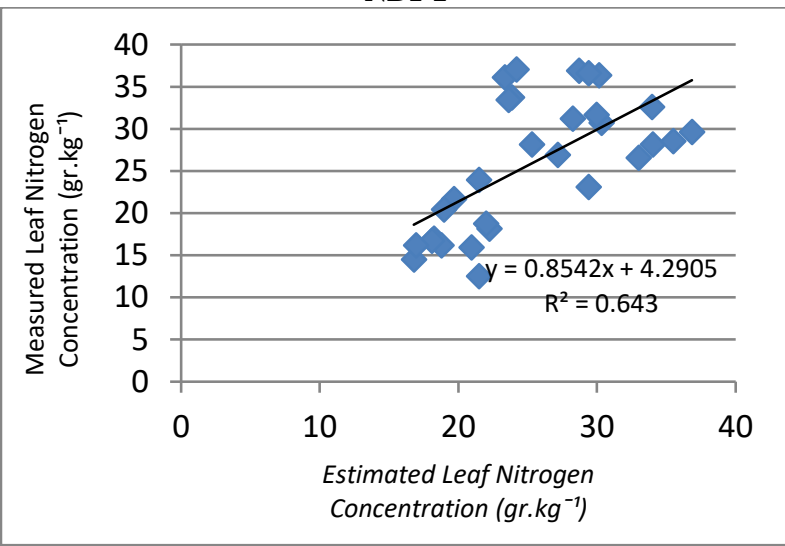

NDI-2

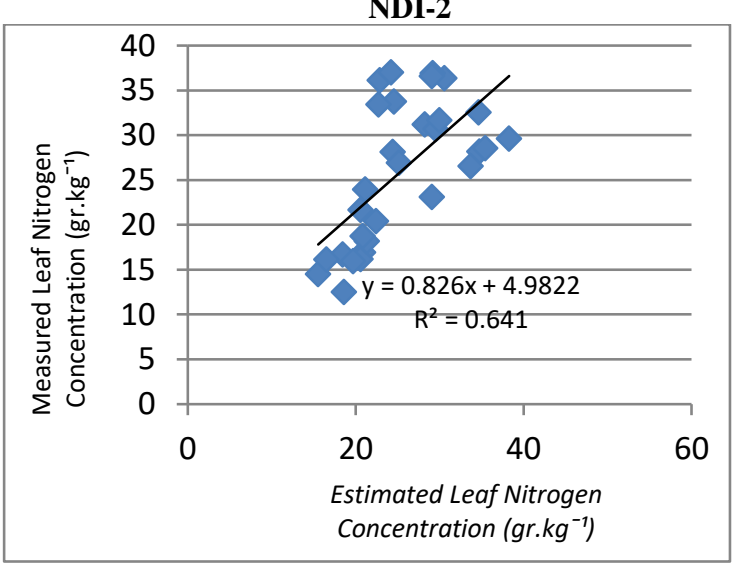

Figure 7. Relationship between estimated and mesured nitrogen content (Early Stage, Feekes 4-7)
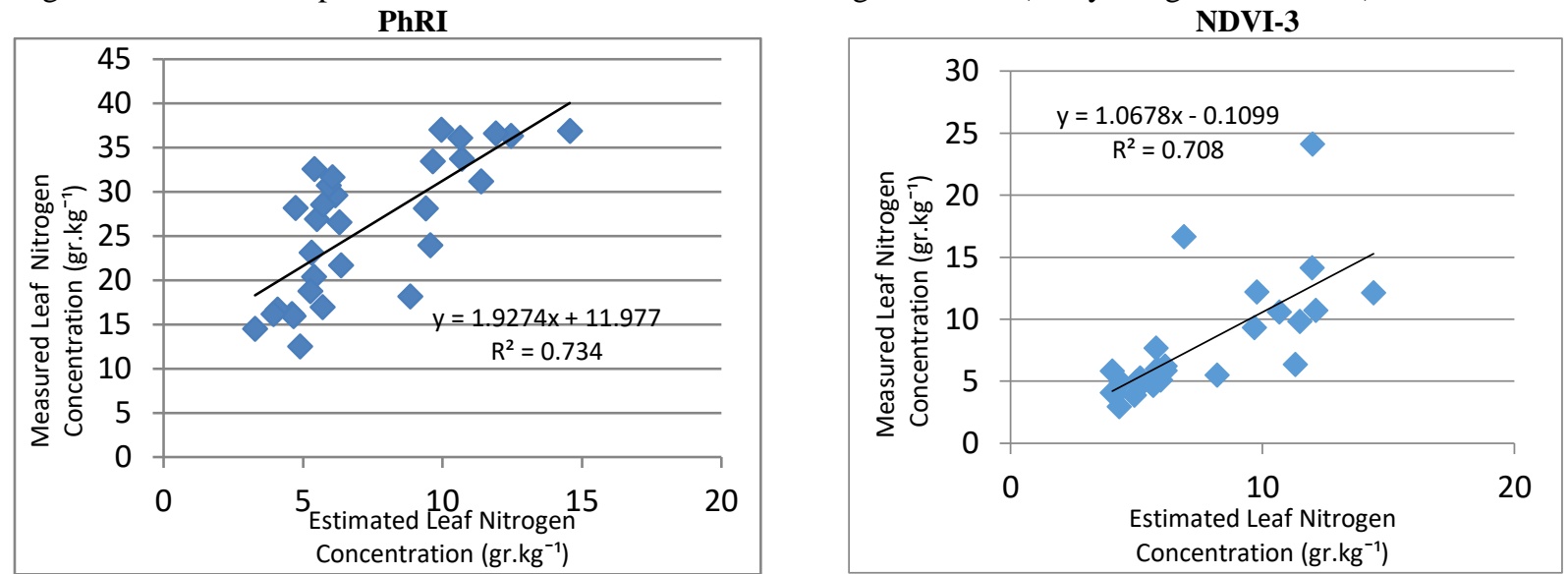

Figure. 8. Relationship between estimated and mesured nitrogen content (Late Stage, Feekes 8-10) 

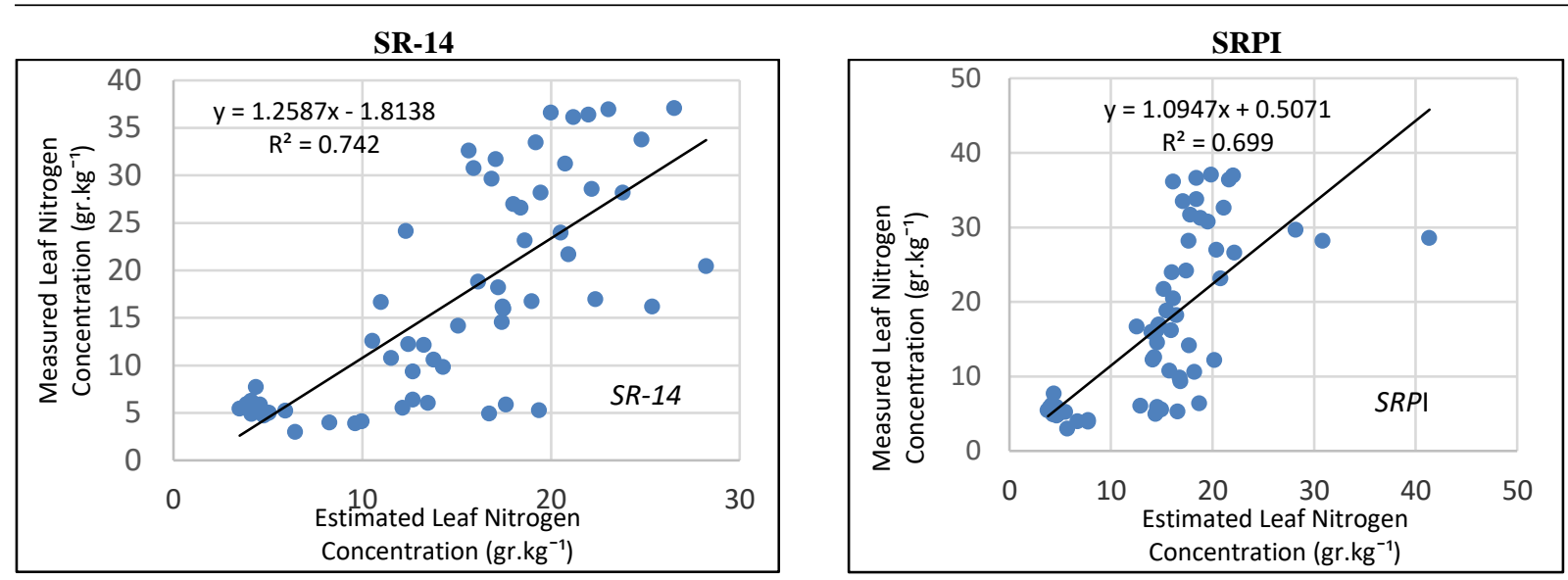

Figure. 9. Relationship between estimated and mesured nitrogen content (All Growing Period, Feekes 4-10)

\section{Conclusions}

The spectral readings were obtained from field experiment during four different growing stages of wheat in Haymana. The results are evaluated in two main stages. One of them is early stage which includes tillering (feekes 4, Zadoks 30) phase and the second leaf node formation (feekes 7, Zadoks-32) phase (jointing) (May 07, 2013). The other is late stage which includes the new formation of last leaf (feekes 8, Zadoks-37) phase, heading (june 06,2013) and completed formation of last leaf (feekes 10, Zadoks-45) stage which is known as Ripening phase (July 04, 2013).Red Edge region (723$766 \mathrm{~nm}$.) and the Near Infrared (NIR) (1033-1127 nm.) region showed the highest correlation according to the analysis between plant spectral reflectance and the values of plant nitrogen concantration (gr kg-1). When evaluating indices for determining leaf Nitrogen content for different growing stages most effective bands are;

In early developing period; Red + Red Edge+Near Infrared bands, the range of $708-850 \mathrm{~nm}$. In late developing period; Visible (Blue+Green+Red) +Red Edge+Near Infrared (NIR) bands, the range of 445-827 nm wavelength.

Whole growing period (2012-2013 season); Visible (Blue+Green+Red) +Red Edge bands, the range of 415$800 \mathrm{~nm}$ wavelength. In the early period, Near Infrared (NIR) (996-1134 nm), Red Edge (red edge) (723-766 $\mathrm{nm}$.), ultraviolet and blue bands $(337-395 \mathrm{~nm})$ showed high correlations. $\left(R^{2}=-0,672-0,334\right)$. In the late period, Near Infrared (NIR) (1004-1128 nm), Red Edge (714-773 $\mathrm{nm}$.), Ultraviolet and blue bands (337-405 nm.) showed a high determination coefficient between bands. $\mathrm{R}^{2}=$ 0,777-(0,636). During whole growing period, the highest correlations were observed in the region Red Edge (700$750 \mathrm{~nm}$.), Ultraviolet and blue bands (334-406 nm.) and Near Infrared (NIR) $(999-1108 \mathrm{~nm}) \mathrm{R}^{2}=-0,848-(0,353)$.

\section{Acknowledgement}

This Study was carried under the project of "Determination of the Effects of Different Nitrogen Application Rates on Yield and Hyperspectral Characteristic on Wheat" with the finance of Ministry of
Agriculture of Turkey (TAGEM/ TSKAD/ 14/A13/P08/05)

\section{References}

AACC, C. (2000). Approved methods of the American association of cereal chemists. Methods, 54, 21.

Aparicio, N., Villegas, D., Casadesus, J., Araus, J. L., Royo, C. (2000). Spectral vegetation indices as nondestructive tools for determining durum wheat yield. Agronomy Journal, 92 (1), 83-91.

Bagheri, F. (2016). Mapping Drought Hazard Using SPI index And GIS (A Case study: Fars province, Iran), International Journal of Environment and Geoinformatics (IJEGEO), 3(1), 22-28.

Birth, G. S., McVey, G. R. (1968). Measuring the Color of Growing Turf with a Reflectance Spectrophotometer 1. Agronomy Journal, 60 (6), 640643.

Broge, N. H., Leblanc, E. (2001). Comparing prediction power and stability of broadband and hyperspectral vegetation indices for estimation of green leaf area indice and canopy chlorophyll density. Remote sensing of environment, 76 (2), 156-172.

Carter, G. A., Spiering, B. A. (2002). Optical properties of intact leaves for estimating chlorophyll concentration. Journal of environmental quality, 31 (5), 1424-1432.

Curran, P. J. (1989). Remote sensing of foliar chemistry. Remote sensing of environment, 30(3), 271-278.

Das S, Roy Choudhury M, Gandhi S, Joshi V (2016) Application of earth observation data and standardized Precipitation Index based approach for meteorological drought monitoring, assessment and orediction over Kutch, Gujarat, India. International Journal of Environment and Geoinformatics 3(2):2437. https://doi.org/10.30897/ijegeo.306468.

Daughtry, C. S. T., Walthall, C. L., Kim, M. S., De Colstoun, E. B., McMurtrey Iii, J. E. (2000). Estimating corn leaf chlorophyll concentration from leaf and canopy reflectance. Remote sensing of Environment, 74 (2), 229-239.

Elvidge, C. D., Chen, Z. (1995). Comparison of broadband and narrow-band red and near-infrared vegetation indices. Remote sensing of environment, 54(1), 38-48. 
Esetlili, M., Bektas Balcik, F., Balik Sanli, F., Kalkan, K., Ustuner, M., Goksel, Ç., Gazioğlu, C., Kurucu, Y. (2018). Comparison of Object and Pixel-Based Classifications For Mapping Crops Using Rapideye Imagery: A Case Study Of Menemen Plain, Turkey. International Journal of Environment and Geoinformatics, 5(2), 231-243. doi: 10.30897/ijegeo.442002.

Fava, F., Colombo, R., Bocchi, S., Meroni, M., Sitzia, M., Fois, N., Zucca, C. (2009). Identification of hyperspectral vegetation indices for Mediterranean pasture characterization. International Journal of Applied Earth Observation and Geoinformation, 11 (4), 233-243.

Fernandez, S., Vidal, D., Simon, E., SOL13-SUGRANES, L. (1994). Radiometric characteristics of Triticum aestivum cv, Astral under water and nitrogen stress. International Journal of Remote Sensing, 15(9), 18671884.

Gamon, J. A., Penuelas, J., Field, C. B. (1992). A narrow - waveband spectral indices that tracks diurnal changes in photosynthetic efficiency. Remote Sensing of environment, 41(1), 35-44.

Gitelson, A.A., Merzlyak, M. N. (1996). Signature analysis of leaf reflectance spectra: algorithm development for remote sensing of chlorophyll. Journal of plant physiology, 148 (3-4), 494-500.

Haboudane, D., Miller, J. R., Tremblay, N., ZarcoTejada, P J., Dextraze, L. (2002). Integrated narrowband vegetation indices for prediction of crop chlorophyll content for application to precision agriculture. Remote sensing of environment, 81 (2-3), 416-426.

Hansen, P. M., Schjoerring, J. K. (2003). Reflectance measurement of canopy biomass and nitrogen status in wheat crops using normalized difference vegetation indices and partial least squares regression. Remote sensing of environment, 86 (4), 542-553.

Huete, A. R. (1988). A soil-adjusted vegetation indice (SAVI). Remote sensing of environment, 25(3), 295309.

İmamoğlu, M., Sertel, E. (2016). Analysis of Different Interpolation Methods for Soil Moisture Mapping Using Field Measurements and Remotely Sensed Data. International Journal of Environment and Geoinformatics, 3(3), 11-25. doi. 10.30897/ijegeo.306477.

Kahriman F., Demirel K., İnalpulat M., Egesel C.Ö., Genç L. (2016). Using Leaf Based Hyperspectral Models for Monitoring Biochemical Constituents and Plant Phenotyping in Maize, Journal of Agricultural Science And Technology, 18, 1705-1718.

Küçük, S., Yüksel, SE. (2020). Unmixing of Hyperspectral Data Using Spectral Libraries, International Journal of Environment and Geoinformatics, 7(1), 93-101. doi.org/10.30897/ijegeo.649394.

Li, F., Gnyp, M. L., Jia, L., Miao, Y., Yu, Z., Koppe, W. Zhang, F. (2008). Estimating N status of winter wheat using a handheld spectrometer in the North China Plain. Field Crops Research, 106 (1), 77-85.

Li, F., Miao, Y., Hennig, S. D., Gnyp, M. L., Chen, X., Jia, L., Bareth, G. (2010). Evaluating hyperspectral vegetation indices for estimating nitrogen concentration of winter wheat at different growth stages. Precision Agriculture, 11 (4), 335-357.

Nasirzadehdizaji, R., Balik Sanli, F., Abdikan, S., Cakir, Z., Sekertekin,A., Ustuner, M. (2019). Sensitivity analysis of multi-temporal sentinel-1 SAR parameters to crop height and canopy coverage Appl. Sci., 9 (4) 655.

Pen Uelas, J., Filella, I., Lloret, P., $\mathrm{MUN}^{-}$OZ, F., Vilajeliu, M. (1995). Reflectance assessment of mite effects on apple trees. International Journal of Remote Sensing, 16(14), 2727-2733.

Penuelas, J., Baret, F., Filella, I. (1995). Semi-empirical indices to assess carotenoids/chlorophyll a ratio from leaf spectral reflectance. Photosynthetica, 31 (2), 221 230.

Roujean, J. L., Breon, F. M. (1995). Estimating PAR absorbed by vegetation from bidirectional reflectance measurements. Remote sensing of Environment, 51 (3), 375-384.

Rouse, J.W., Haas, R. H., Schell, J. A.and Deering, D. W. (1973). Monitoring vegetation system in great plains with ERTS. Proc. 3rd ERTS-1 Symp, GSFC, NASA, SP-351. 48-62.

Schepers, J. S., Hagopian, D. S., Varvel, G. E. (1998, January). Monitoring crop stresses. In Illinois fertilizer conference proceedings (pp. 26-28).

Stroppiana, D., Boschetti, M., Brivio, P. A., Bocchi, S. (2009). Plant nitrogen concentration in paddy rice from field canopy hyperspectral radiometry. Field crops research, 111 (1-2), 119-129.

Tucker, C. J. (1979). Red and photographic infrared linear combinations for monitoring vegetation. Remote sensing of Environment, 8 (2), 127-150.

Turner, D. P., Cohen, W. B., Kennedy, R. E., Fassnacht, K. S., Briggs, J. M. (1999). Relationships between leaf area indice and Landsat TM spectral vegetation indices across three temperate zone sites. Remote sensing of environment, 70 (1), 52-68.

Üstüner, M.; Sanli, F.B.; Abdikan, S.; Esetlili, M.T.; Kurucu, Y. (2014). Crop type classification using vegetation indices of rapideye imagery. Int. Arch. Photogramm. Remote Sens. Spat. Inf. Sci. ISPRS Arch. 40, 195-198.

Vogelmann, J. E., Rock, B. N., Moss, D. M. (1993). Red edge spectral measurements from sugar maple leaves. Title Remote sensing, 14 (8), 1563-1575.

Wei, F., Yan, Z., Yongchao, T., Weixing, C., Xia, Y., Yingxue, L. (2008). Monitoring leaf nitrogen accumulation in wheat with hyper-spectral remote sensing. Acta Ecologica Sinica, 28(1), 23-32.

Zarco-Tejada, P. J., Pushnik, J. C., Dobrowski, S., Ustin, S. L. (2003). Steady-state chlorophyll a fluorescence detection from canopy derivative reflectance and double-peak red-edge effects. Remote Sensing of Environment, 84(2), 283-294. 